\title{
Impact of Occupational Stress and Demographic Variables at Software Development Professional's Performance a Field at Jordanian Software Companies
}

\author{
Amineh A. Khaddam, Mohammed A. Abusweilem
}

\begin{abstract}
The study aims to investigate the differences in the perception of stress based on demographic factors, and the impact of occupational stressat software development professional's performance. The study sample consisted of 116 respondents working in (20)Jordanian software Company which located in Amman, Irbid and Zarqa.The result showsa statistically significant effect at the level of $(P \leq 0.05)$ for occupational stress among software development professional's performance in the Jordanian software Companies.
\end{abstract}

Key words: occupational stress; performance; software Companies

\section{INTRODUCTION}

Stress is measured as communication between events outside the organism which pressure or wellbeingand its responses to them (Ivancevich et al., 2011). Stresses become understandable from the difference between person ability and her or hissurroundings (Affum-Osei\&Azunu, 2016). This difference be able to occur at different level such that stress may result if there is a differentiation between the organization demands. The ability of managerial,software development professionals be different from demographic factors of view (Asmita\& Bhola,2012). It is possible for difference between objectives work surroundings and the employees' subjective perception of work surroundings that may lead into stress Balakrishnan, (2009).

Also(Ivancevich et al., 2011) pointed Stress referred to antecedent of illness as well as asignificant causal representative in health complicationlike hearts disease, stomach painful, sleeplessness

Vimala\&Madhavi(2009); Shirom, (2003); Wang, et al., (2007)indicated the higher level of stress may lead to suicide or other physical problems and this situations leading to absence job frustration above results consistent with Kivimak et al., 2006 andKaren et al., 2006.

Occupational stress as (NIOSH) defined it as the hurtful emotionaland physical responses that happen when worknecessities do not counterpart the needs of the employees orcapability, resource,.leading to poor health. As known place of work stress is the due to the relations between

Revised Version Manuscript Received on 10, September 2019.

Dr. Amineh A. KhaddamManagement Information Systems Department, Faculty of Business, Amman Arab University, jordan street، Jordan

Dr.Mohammed A. Abusweilem, American University in the Emirates, Dubai International Academic City, United Arab Emirates a person and their work surroundings. cause outside the place of work, such as, family problems, physical health, or poor mental or, can cause stress(National Institute for Occupational Safety and Health,2008).

Therearelessprevious literature on systems workforce. The present study is an attempt to discover theimpact of occupational stress with the Demographic variablesamong software development professional'sperformance in Jordanian software Companies and the link between stress levels and demographic variables. which specialize in software development, systems analysts deliver and develop software, designers, testers and others who directly occupied of the software activities.

Software development Professionals (SDP).consists of, programmers, system specialists, are Software development process starts with the Business Manager. As known the software Companies play a significant role in the local economy and with globalization its depend on the information technology in all their process and activities for there the (SDP)who work in the software Companies take into their consideration because they work to support all the others companies to help them to continuous their business. Which need more concentrated otherwise it might leading to affect negatively in software companies and other companies received IT support from them productivity. Thepresentresearch study will focus on the Impact of occupational stress and Demographic variables at software development professional's performance in Jordanian software companies

\section{RESEARCH PROBLEM}

There is a limited previous literature conducted on Impact of occupational stress and Demographic variables (Age , Gender, ,Dally working hours), at software development professional's performance especially in Jordanas one of development nations. Andbecause Jordan is a host country for investors, and they need software ware developer to support their companies with IT services, for there (SDP)might affected byOccupationstress.According to the results of the current study, will proposed advices might benefit to (SDP) in order to avoid the factors affecting occupational stress.Also no study has been done in this regard in Jordanian

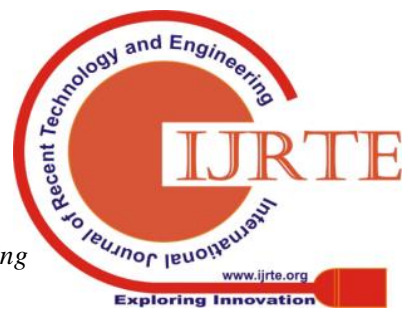


softwarecompaniesaccording to the researcher knowledge. Butmany of pervious literatures done in developed countries and find out inconsistent results, the current study attempt to find result on the Impact of occupational stress and Demographic variables at software development professional's performance in Jordan as a development country.

\section{SIGNIFICANT OF THE STUDY}

In the $80^{\text {th }}$ of the last century the world moved from the industrial economy to the globalization So the competition between business has been increased, each organization struggling to survive among this huge competition ,each organization attempt to provide a quality services and goods, for thereOrganizations seek to attract highly qualified human resources especially Information technology professionals as they are a source of competitive advantage .The current study attempt to know the result of the Impact of occupational stress and Demographic variables(Age , Gender, ,Dally working hours). at software development professional's performance as a significant topic in nowadays business among the huge competition .(SDP) who are technically provide the companies with the IT services must take into consideration all the factors that affect them negatively or positively to proposed recommendations that improved their performance.

\section{OBJECTIVE OF THE STUDY}

The presentstudyobjectiveis to investigate the set Impact of occupational stress and Demographic variables(Age , Gender, ,Dally working hours).at software development professional's performance in Jordanian Software companies. This objective is motivated especially no study has been done in this regard in this environment (Jordan)as a development country.

\section{RESEARCH MODEL}

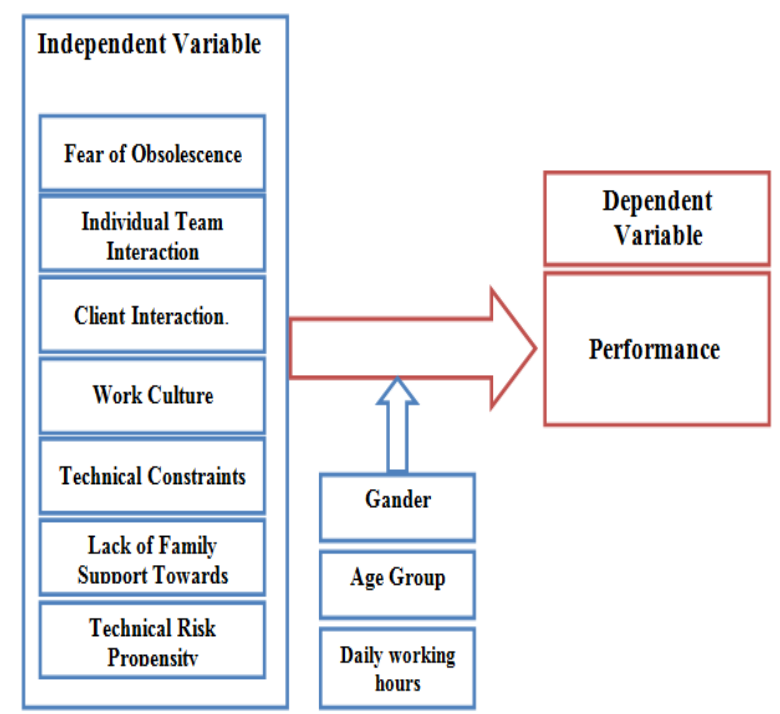

Developed by the Researcher dependent in the Literature review

(Palmer et al., 2005; Thory, 2013; Mohan \& Ashok, 2011; Tarafdar et al., 2011; Tandon et al., 2014).

\section{HYPOTHESIS}

H01:There were no significant differences in the level of occupational stress according to the demographic variables (gender-age group- daily working hours)of the software developer in Jordan software companies.at the level of significance $(\mathrm{P} \leq 0.05)$

H02:There were no significant differences in the level of occupational stress according to the demographic variables (gender-age group- daily working hours)of the software development professionals performance in Jordan software companies.at the level of significance $(\mathrm{P} \leq 0.05)$.

\section{LITERATURE REVIEW}

Many of previous studies investigated the prevalence and associated factors of occupational stress among employees (Tarafdar et al., 2011 Thory, 2013; Mohan \& Ashok, 2011 Tandon et al., 2014 ). Such as, Tandon et al., 2014 presented in their studies on the topic of occupational stress especially related to assessment between gender observed that women less stress than men. Aziz (2004) pointed unmarried among employees, less stress than married employees experience.Thory, 2013; Mohan \& Ashok,(2011)(Tarafdar et al., 2011;). On the other hand, (Michael etal., 2009;Sethi et al., 2004; Antonia et al., 2006;).find out men employee less stress than women employees experience.which inconsistent withZaki and Ali (2009) foundout married women having less stress than unmarried employees. Sharma et.al (2012) reported less stress among low income group than highincome .

Vimala\&Madhavi, 2009, indicated that the stress seem to be higher with increasing age among banks employee. Jeyaraj (2013)findoutaimportantassociation between age and stress level amongstteachers at secondary schools. A consistent results showed by(Affum-Osei et al., 2014)which indicated a positive relationship on occupational stress and performance among SMEs employees also age and occupational stress, with (Affum-Osei, 2016) which had Similar results were obtained for the bank employees. On the dissimilar,(Tandon et al., 2014) (Antonia 2006) indicated that old people had less stress than others. Rauschenbach et al. (2013) reported that there is no relationship between occupational stress and age. A research study by Mutawa et al., (2014) on the factors influencing the occupational stress among university lecturer showed no difference on the level of stress with respect to age

Guardian(2012)indicatedsome teachers having leavesbecause of stress and this result amplified by $10 \%$ inprevious4 years, according to The FOI requested find that $80 \%$ of authorities who responded to statistic conducted by FOI shown increase the teachers number whom having leavesincreasingbecause of stress among the academic years 2008-9 and 2011-12. The severestincrease were inWalsall ( 27 to 74)and Tower Hamlets in London (16 jumped to 102 cases).Also according to the financial services providers teachers survey conducted in $201356 \%$ believed they would likesurelywill do much better in work if they have less stress 
Ranjit and Mahespriya (2012) indicatedless stress with younger age of software employees. Sethi et al. (2004) find out that increases in the demographic factorsresultin high stress for ISP.Few researchers have find out no differences in stress among groups based on demographic factors like Shirom, A. (2003). There seems few research resulted on stress among ISP like (Ivancevich et al., 2004). The present research study is an investigative to fill the research gap in this area.

\section{METHODOLOGY}

The study sample consisted of 116 respondents. 116 questionnaires were spread to the labors working as a softwaredevelopment professionals. They were working in (20)Jordanian software Company which located in Amman ,Irbed and Zarqa. all the respondents having at least one year still working to more than (10 years)experience.

Context of information. Based on the discussion and interaction with (SDP),items was adapted fromRajeswari and Anantharaman (2003) representing sources of stressarise from different types of activities such as organizational policies, team management, project management issues, dealing with diverse work culture, work family, dealing with clients, shortage of skills, resource constraints, , etc. The participate were required to mark the degree of stress on a five pointscale ranging from very low intensity (1) - very high intensity (5).

Table (1)

Study Sample Distribution according demographic variable

\begin{tabular}{|l|l|l|l|}
\hline \multirow{2}{*}{ Gander } & Male & Frequency & Percent \\
\cline { 2 - 4 } & Female & 21 & $81.9 \%$ \\
\hline \multirow{3}{*}{ Age group } & $\begin{array}{l}\text { Less than } \\
\text { 30 }\end{array}$ & 35 & $18.1 \%$ \\
\cline { 2 - 4 } & $\begin{array}{l}\text { More } \\
\text { than 30 }\end{array}$ & 81 & $30.2 \%$ \\
\hline \multirow{2}{*}{$\begin{array}{l}\text { Daily working } \\
\text { hours }\end{array}$} & $\begin{array}{l}\text { Less than } \\
\text { 10 }\end{array}$ & 49 & $69.8 \%$ \\
\cline { 2 - 4 } & $\begin{array}{l}\text { More } \\
\text { than10 }\end{array}$ & 67 & $42.2 \%$ \\
\hline
\end{tabular}

From the above table conclude thatmost of the respondents were male with percent $(95 \%)$, and most of them were in the age group (more than 30 years)with percent $(81.9 \%),(57.8 \%)$ of them working for more than 10 hoursdaily.

\section{RESULT\& DISCUSSION}

Testing the first hypothesis: There were no statistically significant differences at the level of significance $(\mathrm{P} \leq 0.05)$ in the level of occupational stress according to the demographic variables (gender-age group- daily working hours)

ANOVA is used to test the hypothesis and analyze if there are differences in the perception of stress based on demographic factors. Thedemographic variables chosen are: gender, age differences, average daily work hour.

\section{1- Gender}

Table (2) Differences in the perception of stress based on gender

\begin{tabular}{|c|c|c|c|c|c|}
\hline \multirow{2}{*}{ No } & \multirow{2}{*}{ Factors } & \multicolumn{2}{|l|}{ Mean } & \multirow{2}{*}{$\mathbf{F}$} & \multirow{2}{*}{ P-value } \\
\hline & & Male & Female & & \\
\hline 1 & $\begin{array}{l}\text { Fear of } \\
\text { Obsolescence }\end{array}$ & 3.01 & 2.97 & 0.45 & 0.71 \\
\hline 2 & $\begin{array}{l}\text { Individual } \\
\text { Team } \\
\text { Interaction }\end{array}$ & 2.99 & 2.99 & 0.67 & 0.66 \\
\hline 3 & $\begin{array}{l}\text { Client } \\
\text { Interaction. }\end{array}$ & 3.02 & 2.96 & 0.44 & 0.54 \\
\hline 4 & Work Culture & 2.98 & 3.01 & 0.58 & 0.59 \\
\hline 5 & $\begin{array}{l}\text { Technical } \\
\text { Constraints }\end{array}$ & 2.97 & 3.00 & 0.22 & 0.57 \\
\hline 6 & $\begin{array}{ll}\text { Lack } & \text { of } \\
\text { Family } & \\
\text { Support } & \\
\text { Towards } & \\
\text { Career } & \end{array}$ & 2.82 & 3.04 & 0.25 & 0.61 \\
\hline 7 & $\begin{array}{l}\text { Technical } \\
\text { Risk } \\
\text { Propensity }\end{array}$ & 2.95 & 3.00 & 0.39 & 0.68 \\
\hline
\end{tabular}

The data of the above table indicate that: no statistically significant variancesamong the level of occupational stress in the sample of the study according to their gender. P-value more than the statistical error (0.05), this mean the level of occupational stress of the software development professional's didn't differ according to their gender (male female), they are visible to the stress at same level.

\section{2-Age group}

Table (3) Differences in the perception of stress based on age group

\begin{tabular}{|c|c|c|c|c|c|}
\hline \multirow[b]{2}{*}{ No } & \multirow[b]{2}{*}{ Factors } & \multicolumn{2}{|c|}{ Mean } & \multirow[b]{2}{*}{$\mathbf{F}$} & \multirow[b]{2}{*}{ P-value } \\
\hline & & $\begin{array}{l}\text { Less } \\
\text { than } \\
30\end{array}$ & $\begin{array}{l}\text { More } \\
\text { than } \\
\mathbf{3 0}\end{array}$ & & \\
\hline 1 & $\begin{array}{l}\text { Fear of } \\
\text { Obsolescence }\end{array}$ & 2.97 & 3.20 & 1.47 & $0.001 * *$ \\
\hline 2 & $\begin{array}{l}\text { Individual } \\
\text { Team } \\
\text { Interaction }\end{array}$ & 2.99 & 3.00 & 0.22 & 0.71 \\
\hline 3 & $\begin{array}{l}\text { Client } \\
\text { Interaction. }\end{array}$ & 2.87 & 3.12 & 1.62 & $0.000 * *$ \\
\hline 4 & Work Culture & 2.85 & 3.33 & 1.72 & $0.000 * *$ \\
\hline 5 & $\begin{array}{l}\text { Technical } \\
\text { Constraints }\end{array}$ & 2.99 & 2.91 & 0.78 & 0.21 \\
\hline 6 & $\begin{array}{ll}\text { Lack } & \text { of } \\
\text { Family } & \\
\text { Support } & \\
\text { Towards } & \\
\text { Career } & \end{array}$ & 2.98 & 3.01 & 0.58 & 0.22 \\
\hline 7 & $\begin{array}{l}\text { Technical } \\
\text { Risk } \\
\text { Propensity }\end{array}$ & 3.00 & 3.01 & 0.66 & 0.12 \\
\hline
\end{tabular}

** Significant at (0.01) level. 
The data of the above table indicate that:

- There were statistically significant variances at $(\mathrm{P}=$ 0.05 ) in the occupational stress dimensions: (Fear of Obsolescence, Client Interaction and Work Culture), these differences to favor age group (more than 30 years).

- No statistically significant variancesamong the level of occupational stress in the sample of the study according to their age group in occupational stress dimensions: (Individual
Team Interaction, Technical Constraints, Absence of Family Support Towards Career, Technical Risk Propensity), $\mathrm{P}$-value more than the statistical error (0.05).

\section{3- Average daily working hours}

Table (4)Differences in the perception of stress based on average daily working hours

\begin{tabular}{|c|c|c|c|c|c|}
\hline \multirow[b]{2}{*}{ No } & \multirow[b]{2}{*}{ Factors } & \multicolumn{2}{|l|}{ Mean } & \multirow[b]{2}{*}{$\mathbf{F}$} & \multirow[b]{2}{*}{ P-value } \\
\hline & & $\begin{array}{l}\text { Less than } \\
10\end{array}$ & $\begin{array}{l}\text { More than } \\
10\end{array}$ & & \\
\hline 1 & Fear of Obsolescence & 3.22 & 2.92 & 2.11 & $0.000 * *$ \\
\hline 2 & $\begin{array}{ll}\text { Individual } & \text { Team } \\
\text { Interaction } & \end{array}$ & 3.19 & 2.87 & 2.02 & $0.000 * *$ \\
\hline 3 & Client Interaction. & 3.42 & 2.98 & 3.34 & $0.000 * *$ \\
\hline 4 & Work Culture & 2.11 & 1.92 & 1.79 & $0.010 * *$ \\
\hline 5 & Technical Constraints & 3.33 & 2.88 & 2.97 & $0.000 * *$ \\
\hline 6 & $\begin{array}{l}\text { Lack of Family Support } \\
\text { Towards Career }\end{array}$ & 3.21 & 2.93 & 3.22 & $0.000 * *$ \\
\hline 7 & Technical Risk Propensity & 3.00 & 2.97 & 0.82 & 0.24 \\
\hline
\end{tabular}

** Significant at (0.01) level.

The data of the above table indicate that:

- There were statistically significant variances at $(\mathrm{P}=$ 0.05) in the occupational stress dimensions: (Fear of Obsolescence, Individual Team Interaction, Client Interaction, Work Culture, Technical ConstraintsandLack of
- Family Support Towards Career), these differences to favor average daily working hours (less than 10hours).

- No significant differences as appeared in statistic iamong the level of occupational stress in the sample of the study according to their average daily working hours in occupational stress dimension: (Technical Risk Propensity), P-value more than the statistical error (0.05).

Table (5)Regression test result for impact ofoccupational stressat software development professional's performance

\begin{tabular}{|c|c|c|c|c|c|c|c|c|c|}
\hline $\begin{array}{l}\text { Dependent } \\
\text { variable }\end{array}$ & \multicolumn{2}{|c|}{$\begin{array}{l}\text { Model } \\
\text { summery }\end{array}$} & \multicolumn{3}{|c|}{ ANOVA } & \multicolumn{4}{|l|}{ Coefficient } \\
\hline \multirow{8}{*}{ Performance } & $\mathrm{R}$ & $\mathrm{R}^{2}$ & $\mathrm{~F}$ & df & Sig F & Item & $\beta$ & $\mathrm{t}$ & Sig F \\
\hline & \multirow{7}{*}{-0.78} & \multirow{7}{*}{0.62} & \multirow{7}{*}{10.209} & \multirow{7}{*}{4} & \multirow{7}{*}{0.000} & $\begin{array}{l}\text { Fear of } \\
\text { Obsolescence }\end{array}$ & -0.410 & 3.415 & $0.001 * *$ \\
\hline & & & & & & $\begin{array}{l}\text { Individual } \\
\text { Team } \\
\text { Interaction }\end{array}$ & -0.269 & 4.213 & $0.04 *$ \\
\hline & & & & & & $\begin{array}{l}\text { Client } \\
\text { Interaction. }\end{array}$ & -0.381 & 3.662 & $0.007 * *$ \\
\hline & & & & & & Work Culture & -0.541 & 3.991 & 0.000 ** \\
\hline & & & & & & $\begin{array}{l}\text { Technical } \\
\text { Constraints }\end{array}$ & -0.395 & 3.872 & $0.02 *$ \\
\hline & & & & & & $\begin{array}{l}\text { Lack of Family } \\
\text { Support } \\
\text { Towards Career }\end{array}$ & -0.298 & 4.215 & $0.000 * *$ \\
\hline & & & & & & $\begin{array}{l}\text { Technical Risk } \\
\text { Propensity }\end{array}$ & -0.301 & 4.221 & $0.000 * *$ \\
\hline
\end{tabular}

* Significant at (0.05) level.

** Significant at (0.01) level.

The results of the table (5) conclude thatcorrelation coefficient $(\mathrm{R}=-0.78)$ shows the negative and strong relationship between the dependent andindependent variable, and that the impact of the independent variables (occupational stress) on the dependent variable (software development professional's performance) is a statistically significant, where the value of (F calculated) (10.209) and the level of significance ( $\operatorname{sig}=0.000)$ which is less than $(0.01)$. Where it appeared that the value of the coefficient of determination $\left(\mathrm{R}^{2}=0.62\right)$, pointing out that $(62.0 \%)$ of the variance in (software development professional's

\section{Published By:}

Blue Eyes Intelligence Engineering 
performance) can be explained by the variation in (occupational stress).

The Coefficient table showed that the value of $(\beta)$ on dimension(Fear of Obsolescence) have reached (-0.410) and has a value of (t) is (3.41), and the level of significance ( $\mathrm{sig}=$ 0.001), suggesting that the impact of this dimension is significant.

The value of $(\beta)$ on dimension (Individual Team Interaction) had reached to $(-0.269)$ and the value of $(t)$ are (4.213) and the level of significance ( $\mathrm{sig}=0.040)$, indicating that the impact of this dimension is significant ,the value of $(\beta)$ at dimension (Client Interaction) $(-0.381)$ and $(\mathrm{t})$ value is (3.662) at the significance level $(\mathrm{sig}=0.007)$, suggesting that the dimension impact is significant.

The value of ( $\beta$ )on dimension (Work Culture) had reached to $(0.541)$ and the value of $(\mathrm{t})$ are (3.991) and the level of significance $(\mathrm{sig}=0.000)$, indicating that the impact of this dimension is significant, the value of $(\beta)$ at dimension (Technical Constraints) $(-0.395)$ and $(\mathrm{t})$ value is (3.872) atthe significance level ( $\mathrm{sig}=0.020)$, suggesting that the dimension impact is significant.

The value of $(\beta)$ on dimension (Lack of Family Support Towards Career) had reached to (-0.298) and the value of (t) are (4.215) and the level of significance ( $\operatorname{sig}=0.000$ ), indicating that the impact of this dimension is significant, the value of $(\beta)$ at dimension (Technical Risk Propensity) (-0.301 ) and $(\mathrm{t})$ value is (4.221) at the significance level ( $\mathrm{sig}=$ $0.000)$, suggesting that the dimension impact is significant.

From the above analysis, we reach to not accept the second main null hypothesis, means accepting the hypothesis: (There is a statistically significant effect at level $(\mathrm{P} \leq 0.05)$ for occupational stress on the software development professional's performance in the Jordanian software Companies). The current result consistent with other studies like (Affum-Osei et al., 2014) (Affum-Osei, 2016) might taken same factors the current study has been taken, and inconsistent with scholars like ,( Tandon et al., 2014) (Antonia 2006) Rauschenbach et al. (2013) Mutawa et al., (2014) Ranjit and Mahespriya (2012) ,Sethi et al. (2004) might their studies conducted in different environments.

\section{CONCLUSION AND RECOMMENDATIONS}

The study highlights some of the factors that cause stress among software development professionals. The difference between the applicability of current research results and previous studies is that this study focuses more on software development professionals in Jordan and their specific work environment, and therefore more reflective of the actual tasks of work and work behaviors. Specialists in software development. As a result, interventions can be tailor-made to meet the needs of specific groups.

The study also examined the impact of the level of occupational stress on the performance in thesoftware development professional's companies, where it reached that the stress of work in different dimensions adversely affect performance. Therefore, the management of companies should pay attention to the pressure of work, By increasing the level of performance and not exposing the performance of workers to decline and create the suitable environment to the (SDP) andshould the managementofthecompanies avoid them of the work pressures alsopermitted to work for flexible time in regard workinghours, which may allow them to achieve home-related everyday jobs as when requiredandtake into account their family circumstances .

\section{REFERENCES}

1 Affum-Osei, Asante, E. A., \&Barnie, J. (2014). Academic Achievement: The Role ofStress, Self-concept andMotivation.

2 Affum-Osei, E., \&Azunu, C. (2016). Relationship between Occupational Stress and Demographic Variables: AStudy of Employees in a Commercial Bank in Ghana. British Journal of Applied Science \&Technology,12(2), 1-9. https://doi.org/10.9734/BJAST/2016/21460

3 Anshel, M. H. (2000). A conceptual model and implications for coping with stressful events in police work.Criminal Justice and Behavior, 27, 375-400

4 Antonia, A. S., Polychroni, F., \&Vlachakis, A. N. (2006). Gender and age differences in occupational stress and professional burnout between primary and high school teachers in Greece. Journal of ManagerialPsychology, 21(7), 682-690.

5 Asmita, B., \&Bhola, N. G. (2012). Women in Information Technology (IT) sector: A Sociological Analysis.ijbm.ccsenet.org International Journal of Business and Management Vol. 13, No. 12; 2018148IOSR Journal of Humanities and Social Sciences, 3(6), 45-52.

6 Aziz, M. (2004). Role stress among women in the Indian information technology sector. Women in ManagementReview, 19(7), 356-363.

7 Balakrishnan, C., \&Swetha, S. ( 2009 ). Impact of age and level of occupational stress experienced by non-gazetted officers of central reserve police force. Indian Psychiatry Journal, 18(2), 81-83.

8 Ivancevich, J. M., Konopaske, R., \& Matteson, M. T. (2004). Organizational Behavior and Management.McGrawHillGolbal Education Holdings.

9 Jeyaraj, S. S. (2013). Occupational stress among the teachers of the higher secondary schools in Madurai District. Tamil Nadu. IOSR Journal of Business and Management, 63-76.

10 Karen, A., Matthews, S. Z., Diane, C. T., \& Mary, A. W. (2006). Blood Pressure Reactivity to Psychological Stress and Coronary Calcification in the Coronary Artery Risk Development in Young Adults Study.Hypertension, 47, 391-395.

Kivimaki, M., Virtanen, M., Elovainio, M., Konvonen, A., Vaananen, A., \&Vahtera, J. (2006). Work Stress in the etiology of coronary heart disease- : a meta-analysis. Scandinavian Journal of Work Environment, 32(6),431-442.

11 Mohan, N., \& Ashok, J. (2011). Stress and depression experienced by women software professionals in Bangalore, Karnataka. Global Journal of Management and Business Research, 11(6), 24-29

12 Mutawa, A. A., Jdaitawi, M., Saleh, W., \&Awad, A. M. (2014). Psychological strain among academic staff inEastern Saudi Arabia. Proceeding of the Social Sciences Research ICSSR. World Conferences.

13 National Union of teachers(2013).

14 National Institute for Occupational Safety and Health ,(2008).

15 Palmer, B., Gignac, G., Manocha, R., \&Stough, C. (2005)

16 Rajeswari, K. S., \&Anantharaman, R. N. (2003). Development of a scal to measure stress among software professionals: A factor analytic study. In proceedings of the ACM SIGCPR Conference, Phladelphia USA34-43. 
17 Ranjit, L., \&Mahespriya, L. (2012). Study on Job Stress and Quality of life of women software employees.International Journal of Research in Social Sciences, 2(2), 276-291.

18 Rauschenbach, C., Kumm, S., Thielgen, M., \&Hertel, G. (2013). Age and work-related stress: A review and meta-analysis. Journal of Managers Psychology, 28(7), 781-804.

19 Sethi, V., King, R. C., \& Quick, J. C. (2004). What Causes Stress in Information System Professionals?Comminications of the ACM, 47(3), 99-103.

20 Sharma, S. K., Sharma, J., \& Devi, A. (2012). Role stress based on Employee Segmentation. Management, 17(2), 1-30.

21 Shirom, A. (2003). The effects of work stress on health. In M. J.Schabracq, J. A. M. Winnubst and C. L. Cooper (Eds.), Handbook of work and health psychology Hoboken...

22 Tandon, P. K., Mahaur, C., \& Annapurna. (2014). Effect of age and gender on occupational stress on teaching farternity. International Journal of Engineering Technology, Management and Applied Sciences, 2(2),41-46.

23 Tarafdar, M., Tu, Q., Ragu-Nathan, T. S., \&Banu, S. R. (2011). Exploring the factors thay may lead to theinability of professionals to adapt or cope with emerging IS in a healthy manner. Communication of theACM, 54(9), 113-120.

24 Thory, K. (2013). A gendered analysis of emotional intelligence in the workplace issues and concerns for human resource development. Human Resource Development Review, 12, 221-244.

25 Vimala, B., \&Madhavi, C. (2009). A study on stress and depression experienced by women IT professionals in Chennai, India. Psychology Research and Behaviour Management, 2, 81-91.

26 Wang, H. X., Leineweber, C., Kirkeeide, R., Svane, B., Schenck-Gustafsson, K., Theorell, T., \&Orth-Gomer, K.(2007). Psychosocial stress and atherosclerosis: Family and work stress accelerates progression of coronary disease in women. Journal of Internal Medicine, 261(3), 245-254.

27 Zaki, R. M., \& Ali Jalbani, A. (2009). Job Stress among Software Professionals in Pakistan: A Factor Analytic Study. Journal of Independent Studies and Research-Management, Social Sciences and Economics, 7(1),1-17.

28 A.K. Borah and P. Goswami (2017); THE BOUNDARY ELEMENT METHOD TO THE SOLUTION OF HEAT RADIATION PROBLEMS: A NUMERICAL IMPLEMENTATION, International Journal of Engineering and Management, Vol. 4 no. 1; pp 37-44

29 Abderrazak DHAOUI and Fathi JOUINI (2019); R\&D INVESTMENT, GOVERNANCE AND MANAGEMENT ENTRENCHMENT, International Journal of Financial Economics and Econometrics, Vol. 6 no. 2 (2019); pp 69-90

30 Aggelopoulos S. (2017); BUSINESS RANKING BASED ON QUALITATIVE ECONOMIC PARAMETERS: APPLICATION OF A METHODOLOGICAL PATTERN ON SHEEP FARMS, International Journal of Engineering and Management, Vol. 4 no. 2; pp 83-91

31 Arpita Mehta (2017); CUSTOMER ENGAGEMENT: A CONCEPTUAL CASE STUDY, International Journal of Engineering and Management; Vol. 4 No 1; pp 1-11

32 Atsalakis George \&ZopounidisConstantin (2018); FORECASTING TURNING POINTS IN STOCK MARKET PRICES BY APPLYING A NEURO-FUZZY MODEL, International Journal of Engineering and Management, Vol. 5 no. 2 pp 67-76
33 C. D. Lai, (2017)Hazard Rate that Asymptotes to a Constant and Applications, International Journal of Reliability and Quality Performance, Vol. 6 no. 1 pp 1-9

34 Christos Floros, ShabbarJaffry\& YasseenGhulam (2019); PREDICTING RETURNS WITH FINANCIAL RATIOS: EVIDENCE FROM GREECE, International Journal of Financial Economics and Econometrics, Vol. 6 no. 1 (2019)

35 DvenHusmann and VolodymyePerederiy (2017); Forecasting Default with Aggregated Financial Ratios; JOURNAL OF MONEY BANKING and FINANCE; Vol. 1 no. 1 pp 53-68

36 IoannisKekes\&AthanasiosSpyridakos (2018); TOWARDS AN EVALUATION MODEL FOR EDUCATIONAL SOFTWARE ANALYZING EVALUATORS BEHAVIOR THROUGH THE MULTICRITERIA DISAGGREGATION AGGREGATION APPROACH, International Journal of Engineering and Management, Vol. 5 no. 2; pp 53-65

37 Kodo Ito \& Toshio Nakagawa (2017); Optimal Operation Censoring Policy of Aircraft, International Journal of Reliability and Quality Performance, Vol. 6 no. 1 pp 19-25

38 KonstantinosDrakos., Modelling Conditional Volatility of Risk Premia on Fixed Income Instruments, International Economics and Finance Journal, Vol. 1, No. 2, p. 313.

39 Minh Quang Dao (2018); DEMOCRACY AND URBAN POVERTY IN DEVELOPING COUNTRIES, International Journal of Financial Economics and Econometrics, Vol. 5 No. 1, pp 1-10

40 Miniar Ben Ammar and Sami Hammami (2018); THE CAUSES OF THE DEFICIT OF HEALTH BRANCH OF SOCIAL SECURITY IN FRANCE, International Journal of Financial Economics and Econometrics, Vol. 5 No. 1, pp 71-89

41 Mitsuhiro Imaizumi\&Mitsutaka Kimura (2017), Optimal Policy for a System Connected with the Radio Link, International Journal of Reliability and Quality Performance, Vol. 6 no. 1 pp 11-17

42 Mitsuhiro Kimura, Takaji Fujiwara, Tomoki Inoue \&NaomichiHata (2017); A Software Reliability Assessment Method under Imperfect Testing Environment, International Journal of Reliability and Quality Performance, Vol. 6 no. 2 pp 55-64

43 MotasamTatahi and EsraT.Kabaklarli (2017); The Financial and Operating Performance of Privatised Firms in France; JOURNAL OF MONEY BANKING and FINANCE; Vol. 1 no. 1 pp 27-51

44 Muhammad Hustafa and Emmanuel Anoruo (2017); Transmission Effect of Volatility Between Stock Market Returns, Economic Growth and Productivity-Wage Gap; JOURNAL OF MONEY BANKING FINANCE; Vol. 1 no. 2 pp $1-16$

45 Natalie Hegwood and M.H.Tuttle (2017); Did the Mortgage Interest Rate Fail to Respond to Federal Funds Rate Changes: Testing for a Short-Run Break, 2002-2005; JOURNAL OF MONEY BANKING and FINANCE; Vol. 1 no. 1 pp 13-26

46 Nicola Costantino\& Roberta Pellegrino (2018); REAL OPTION APPROACH FOR THE EVALUATION OF INVESTMENT PROJECTS THE CASE OF A MULTI-FUEL POWER STATION, International Journal of Engineering and Management, Vol. 5 no. 2; pp 95-101 
47 Nikolaos Samaras (2017)BASIS UPDATE METHODS IN THE REVISED SIMPLEX METHOD, International Journal of Engineering and Management, Vol. 4 no. 1; pp 13-18

48 Noula Armand Gilbert and NzomoTcheunta Joseph (2018); AGRICULTURAL CRISIS AND ECONOMIC DEVELOPMENT: The African Experience of the 1980s, International Journal of Financial Economics and Econometrics, Vol. 5 No. 1, pp 11-39

49 OlhaBodnar and TarasBodnar (2019); UNBIASED ESTIMATOR OF THE EXPECTED QUADRATIC UTILITY PORTFOLIO, International Journal of Financial Economics and Econometrics, Vol. 6 no. 1, pp 59-68

50 Olusegun H. D. (2017); CHARACTERISTICS OF ENERGY RELEASED DURING MELTING OF ALUMINIUM AND BRASS, International Journal of Engineering and Management, Vol. 4 no. 1; pp 29-35

51 Ran Zhang (2017); Does Systematic Risk Affect A-H Price Spread?; JOURNAL OF MONEY BANKING and FINANCE, Vol. 1 no. 1 pp 1-11

52 Shinji Inoue \& Shigeru Yamada (2017); Optimal Testing-Effort Expending Policies Based on a Two-Dimensional Software Reliability Growth Model; International Journal of Reliability and Quality Performance, Vol. 6 no. 2 pp 65-77

53 Sureshkumar M. R.and V. MadhusudananPillai (2017); IMPACT OF WEIGHT ASSIGNED TO OBJECTIVE FUNCTIONS IN PLANNING ANNUALISED HOURS, International Journal of Engineering and Management, Vol. 4 no. 1; pp 19-27

54 Wahab. A. Lawal and Rihanat. I. Abdulkadir (2018); AN ANALYSIS OF GOVERNMENT SPENDING ON EDUCATIONAL SECTOR AND ITS CONTRIBUTION TO GDP IN NIGERIA, International Journal of Financial Economics and Econometrics, Vol. 5 No. 1; pp 53-70

55 Xiao XIAO* \& Tadashi DOHI (2017); Exponential-Like Software Reliability Models Based on Binomial Process; International Journal of Reliability and Quality Performance, Vol. 6 no. 2 pp 79-87

56 YihuiLan., Equilibrium Exchange Rates an d Currency Forecasts: A Big MAC Perspective, International Economics and Finance Journal, Vol. 1, No. 2, p. 291.

57 Dan Han and Howard Qi(2019); Analyzing the Dynamics of ARM, FRM \& Hybrid Mortgage Loans, Asian Journal of Economics and Finance, Vol. 1 No. 1; pp 1-15

58 DikaiosTserkezos (2019); Detecting ARCH Effects: Power versus Frequency of Observation. Some Monte Carlo results, Asian Journal of Economics and Finance, Vol. 1 No. 1; pp 16-23

59 Yu Chun Wang, Chung Jung Lee and KuoCheng Huang (2019); Corporate Governance, Investment Opportunities and Cash Holdings for SEO Firms: A Test of the Shareholder Power Hypothesis; Asian Journal of Economics and Finance, Vol. 1 No. 1;pp pp 24-46 